\title{
IN TENSIVE CULTIVATION THE GOAL.
}

\author{
BY PROF HOMER C. PRICE, OHIO STATE UNIVERSITY.
}

From the beginning. American agriculture has been characterize by its extensiveness rather than its intensiveness. Land has been more abundant than labo and, in the aggregate, more has been derived from a small yield on a large acreage than could have been realized from a large yield on a small acreage. The yields of American farm crops have been proverbially small, but the total production has been exceptionally large and, as a rule, the countries producing the larg. est amounts of farm crops have the smallest yields per acre. This fact is illustrated in the following table:

\begin{tabular}{|c|c|c|c|}
\hline & $\begin{array}{l}\text { Average Yield } \\
\text { per Acre, } \\
\text { 1888-1897, }\end{array}$ & $\begin{array}{c}\text { A verage Yield } \\
\text { per Acre, } \\
1898-1907 .\end{array}$ & $\begin{array}{c}\text { Total } \\
\text { Production. }\end{array}$ \\
\hline 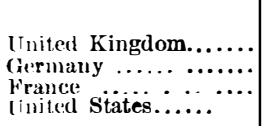 & $\begin{array}{l}\text { Buphels. } \\
30.1 \\
22.7 \\
17.6 \\
12.8\end{array}$ & $\begin{array}{c}\text { Bushels. } \\
33.6 . \\
28.4 \\
28.8 \\
13.9\end{array}$ & 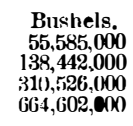 \\
\hline
\end{tabular}

The above table also reveals the fact that the production per acre when compare by ten-year periods las been increasing in all the countries. Much ha been said and is being written about the decline in agricultural production, but statistics do not show that there has been any decline, but rather a marked increase when the productions of the leading countries are compared and using the production of wheat, which is the most universally grown farm crop, as the basi for comparison.

The intensity of culture always bears a direct rela ion to the density of population, and while it is diffcult to get a comparable basis of comparison between countries on account of the varying proportions of waste land in different countries and different methods of classifying statistics, the following table represent the most reliable figures available and, when compared with the preceding table, shows that the yield of whea per acre varies directly as the density of population.

$$
\text { Number of Acres per Capita. }
$$

United Kingdom ................. 1.70 acres. $\begin{array}{lll}\text { Germany } & \ldots \ldots \ldots \ldots \ldots \ldots \ldots \ldots \ldots \ldots \ldots \ldots \ldots \ldots \ldots \ldots & 2.37 \text { acres. } \\ \text { Franes } & 3.40 \text { acres }\end{array}$ United States (exclusive of Alaska and

Philippines)

24.02 acres

In 1900 there were $838,000,000$ acres in farms in the United States, and since then we have been adding to them about 15,000,000 acres each year from the public lands of the country. During this time, however, the population of the country has been increasing at the rate of about one and one half million each year. The public lands of the country that are suitable for agricultural purposes have practically all been taken up; the tide of immigration has been turned back from the Pacific coast, and the competition for land already under cultivation has become much more keen and as a consequence, the values of farm real estate have advance generally throughout the country, but to the greatest extent in the western States. Farm lands in some sections have double or even tripled in value in the course of a few years.

Together with the increased value of farm land have gone other changes that have had an important bearing on the agriculture of the country.

The development of methods of transportation and the extension of railroads through the new agricultura lands have widene the markets of the country, for both buying and selling. The introduction of refrigerator car service has made possible the shipping of fruits, meats and other perishable products across the continent. This has resulte in bringing the product of cheap lands in competition with the products of high-priced land in the eastern States.

Another factor that has had an important bearing in this connection has been the development of laborsaving farm machinery. If the present wheat crop of the Unite States were harvested by the method employed at the time of the civil war, it would require every man of military age in the United States to work for at least two weeks in wheat harvest. The inven tion of labor-saving machinery has increased the producing power of the individual to such an extent that notwithstanding the increase in the agricultural exports of the country from $\$ 205,853,748$ in 1858 to $\$ 1$, $017,396,404$ in 1908 , the percentage of the population engaged in agriculture has decreased by decades a follows:

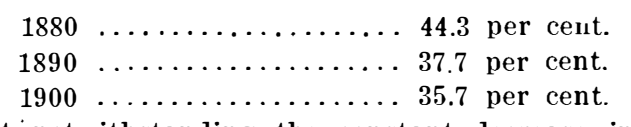

But notwithstanding the constant decrease in the proportion of the population engaged in agriculture, the per capita production for the entire population of the most important classes of agricultural products has increase almost invariably.

The following table gives the average per capita production by decades, 1866-1908. These statistics ar from the United States Department of Agriculture:

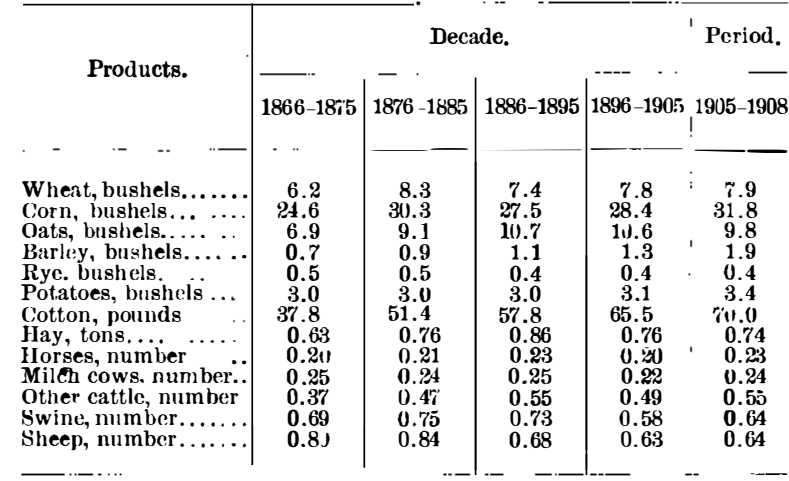

This almost inconceivable increase in agricultura production has been accompanied by changes in agricultural conditions that make a reorganization of American farming methods absolutely necessary.

Foremost among these changes has been the growth of cities from an urban population of 2,897,000, or 12.5 per cent. of the population total, in 1850 , to a population of $24.992,000$ or 33.1 per cent. of the total population in 1900 . This concentration of the population has brought about new problems of food supply in furnishing the more perishable products such as in furnishing the more perishable products such as
milk, vegetables, fruits and such products as need to milk, vegetables, fruits and such prod
be consumed soon after production.

Another condition that has arisen is the tendency of the soil fertility of the farms of the older agricultural sections to become exhausted. To remedy this, the use of commercial fertilizers has become general in the eastern United States and the statistics of 1900 show that $\$ 55,000,000$ worth of goods were used by the farmers of the United States, which was an in crease of 42 per cent over the amount used in 1890 , so that it is probable that not less than $\$ 75,000,000$ per year is spent for this purpose.

The opening up of the Middle West took from the farmer of the eastern States his market for wheat and other grain. He was thrown in competition on the open market with the farmer who had secured his land for practically nothing and land that was much more fertile and productive. The farmer of the Middle West, in turn, has been thrown in competition in the live-stock markets with the live-stock products of the western and southwestern States and Territories. Stock that was raise under range conditions and often on government land free of charge competed with

the Middle West.

While these conditions are not so emphatically true as they were a few years ago, yet the problem is far from being solved and the American farmer is now passing through a transitional stage and the most important problem before him at the present time is the question of reorganizing his farming methods so as to best fit the agricultural conditions as they now exist.

The unprecedented increase of values of farm products in recent years resulting in a greatly increased cost of living to every one has resulted in the most prosperous times the American farmer has ever experienced, except during the civil war by those who stayed at home and reaped the benefits of high prices. The consumer, on the other hand, is alarme at the continued rise in price of the necessities of life. He is interested in knowing what the end is going to be and how much longer prices are going to rise.

Writers who are ill-advised of the potential produc ing power of American farms are freely predicting that we are rapidly approaching the time when as a nation we shall not be able to produce sufficient food stuffs for our own population. They forget that our farms are not producing more than one-half of what they are capable of doing. Our average wheat yield is 14 bushels per acre; our average yicld of corn is 26 bushels, and of oats, 25 bushels; these yields can an products will demand.

The profits of farming in the past galned from actual production have not been in proportion to the profits derived from other industries. The market price of farm products has tended toward the actual cost of production of the average crop at current wages rather than the cost of production of the part of the crop produce under the most unfavorable conditions. This is readily demonstrate by taking the actual amount of time require to grow and harvest an acre of any of the principal crops and calculating the time at current wages and the average yields at farm prices. The results will show that the returns received for the time spent will not be more than enough to pay current wages and six per cent interest on the investment in land and equipment. Farmers have received greater returns from the increased value of their lands than they have from the profits upon their productions.

The increased prices of farm products are beginning to bring to farmers a just return for labor expended and will do more than anything else to turn the city dweller "back to the soil" and to keep the country boy on the farm. There is no danger of a shortage of food supplies in this country, but higher prices must prevail in order to develop the potential agricultural resources of the country. Aside from the possibilities of doubling the present crop production on present area under production, there remains the undeveloped agricultural lands of the country. Aside from the limited amount of land suitable for agricultural pur poses remaining in the ownership of the government, the lands that may become valuable for agricultural purposes are of two kinds-the swamp lands that may be reclaimed by drainage and the arid lands that may be reclaimed by irrigation. The United States Geological Survey estimates that 75,000,000 acres can be made valuable for agriculture by drainage swamps. This is the equivalent of one-sixth of all the land now under cultivation in the United States. This land would be much more fertile and much more productive than the most of the land that is now being cultivated. The reclamation of arid lands is just in its infancy. The first federal act to provide for govern ment assistance for this purpose was passed in 1902 .

Projects are now under construction or have been completed that will reclaim one and a half million acres and others are under consideration that will reclaim three and one-half million. To what extent this work of reclamation will be carried in the future can scarcely be estimated, but doubtless many millions of acres can be and will be added to our cultivable lands in the future.

The period of low prices for farm products and extensive methods of farming is rapidly passing. The large grain and live-stock farms of the eastern States are giving way to the smaller dairy, fruit, vegetable or poultry farm. The large wheat farms of the Northwest are being divided into moderate-sized farms for mixed farming. The ranges of the West and Southwest are being broken up into stock farms, and the movement everywhere is toward more intensive meth. ods of farming.

The problem that now confronts the American farmer is to reorganize his method of farming so as to adapt it to the present conditions. The increased prices for farm products will increase their production and insure a supply sufficient for all needs for the future.

The new Japanese law for the encouragement of native shipbuilding came into operation with the beginning of this year, and includes provisions according to which in the construction of the hull or the machinery for a vessel which is to receive a subsidy, foreign-made materials must not be used except for the following parts, viz.: Stem, stern post, rudder and rudder tiller, rudder post, quadrant and rudder pintles used for vessels of 3,000 tons or more; triple screw shaft bearing; stanchions of not less than 7 inches diameter; all kinds of springs; corrugated and plain or flange furnaces; rotor spindle or shaft. blades and buckets of turbine engine. The following articles use in the equipment of a vessel which is to enjoy the subsidy must not be foreign made, viz.: Windlass, carge winches, steering angine and gear, anchor chains, wire ropes, hawsers, etc., centrifugal pumps, hand pumps, fire pumps, boat and other davits, electric apparatus, auxiliary condenser, steam pumps, dynamo, valves and cocks. Patented articles or articles of new design made abroad can only be used in the construction of hull or machinery or in the equipment of a ship receiving a subsidy with the special permission of the Minister of Communication. 